\title{
The nomogram of intracranial translucency in the first trimester in singletons
}

\section{Tekil gebeliklerdeki birinci trimester fetal intrakraniyel translüsensi nomogramı}

\author{
Rahime Nida Ergin ${ }^{1}$, Murat Yayla ${ }^{2}$ \\ 'Department of Gynecology and Obstetrics, Bayindir Hospital, Istanbul, Turkey \\ ${ }^{2}$ Department of Gynecology and Obstetrics, International Hospital, Istanbul, Turkey
}

\section{Abstract}

Objective: Measurement of intracranial translucency (IT), which is a recent earlier recognizable sonographic marker, has been suggested for detection of spina bifida. In this prospective study we aimed to determine normative values of IT in the population of Turkish singleton pregnant women during the first trimester of pregnancy.

Material and Methods: Between January 2011 and July 2011, all consecutive singleton pregnant women were screened for intracranial translucency. Pregnancies were followed until birth. Pregnancies with any detected/suspicious anatomical or genetic fetal anomalies, biochemical abnormalities, increased nuchal translucency measurements, pregnancies of artificial reproduction techniques and anomaly detected at birth were set to be excluded from the data analyses. Mean \pm standard deviation, median and percentile values of intracranial translucency were calculated. Linear regression analyses were done between the length of intracranial translucency and gestational week and CRL.

Results: Data analyses included 201 fetuses. Median maternal age was 31 years. Median CRL was $62 \mathrm{~mm}$. Median gestational week was 12.57 weeks. Median IT value for the first trimester was $1.7 \mathrm{~mm}$ (range $1.00-2.40)$. Calculated formulae are; IT $(\mathrm{mm})=[0.237 \mathrm{xGestational}$ Week) $]-1.27, \quad \mathrm{R}^{2}=0.302 ; \mathrm{p}<0.001$ and IT $(\mathrm{mm})=[0.020 \mathrm{xCRL}$ $\left.(\mathrm{mm})]+0.44, \mathrm{R}^{2}=0.381 ; \mathrm{p}<0.001\right)$. IT measurements increased with increasing CRL and advancing gestational weeks. During follow up none of the fetuses was found to have any anatomical abnormality or anomaly.

Conclusion: This study presents normative values of intracranial translucency in the first trimester screening of normal singleton pregnancies of the Turkish population. In accordance with previous reports, intracranial translucency increases linearly with advancing CRL. (J Turkish-German Gynecol Assoc 2012; 13: 153-6)

Key words: Screening, spina bifida, intracranial translucency, pregnancy, ultrasonography

Received: 27 February, 2012

Accepted: 09 April, 2012

\section{Özet}

Amaç: Yeni erken saptanabilen sonografik bir marker olan intrakraniyel translüsensi ölçümü sipina bifida varlığının saptanması için önerilmektedir. Prospektif olan çalışmamızda Türk popülasyonundaki tekil gebeliklerde birinci trimester fetal intrakraniyel translüsensi (IT) ölçümlerinin normal dağılımının saptanması amaçlandı.

Gereç ve Yöntemler: Ocak 2011 ve Temmuz 2011 tarihleri arasında tüm ardışık tekil gebelerde intrakraniyel translüsensi ölçümleri bakıldı. Gebeler doğuma kadar takip edildi. Şüpheli veya gösterilen anatomik/genetik fetal anomalileri, biyokimyasal değer anormalliği, artmış nukal kalınlığı yada doğumda anomali saptanan fetuslar ve yardımcı üreme teknikleri uygulanmış fetuslar değerlendirme dışında tutuldu. İntrakraniyel translüsensi için ortalama \pm standart deviasyon, medyan ve persentil değerleri hesaplandı. Lineer regresyon analizleri ile intrakraniyel translüsensi ve gebelik haftası ve CRL arasındaki ilişki saptand..

Bulgular: Veri analizlerine 201 fetus dahil edildi. Medyan anne yaşı 31 yll, medyan CRL $62 \mathrm{~mm}$ ve medyan gebelik haftası 12.57 hafta saptandı. Birinci trimester için medyan IT değeri $1.7 \mathrm{~mm}$ (aralık 1.002.40) bulundu. Hesaplanan formüller; IT $(\mathrm{mm})=[0.237 \mathrm{xGebelik}$ Haftasi $]-1.27, \mathrm{R} 2=0.302 ; \mathrm{p}<0.001$ ve IT $(\mathrm{mm})=[0.020 \times \mathrm{xRL}(\mathrm{mm})]+0.44$, $\mathrm{R} 2=0.381 ; \mathrm{p}<0.001$. IT ölçümleri artan CRL ve ilerleyen gebelik haftası ile birlikte artıyor olarak saptandı. Takip esnasında hiçbir fetusta anomali saptanmadı.

Sonuç: Mevcut çalışmada Türk popülasyonundaki tekil gebeliklerde birinci trimester fetal intrakraniyel translüsensi normal dağılımları gösterilmektedir. Literatür ile uyumlu olarak, intrakraniyel translüsensi ilerleyen gebelik haftası ve CRL ile lineer olarak artmaktadır.

(J Turkish-German Gynecol Assoc 2012; 13: 153-6)

Anahtar kelimeler: Tarama, spina bifida, intrakraniyel translüsensi, hamilelik, ultrason

Geliş Tarihi: 27 Şubat 2012

Kabul Tarihi: 09 Nisan 2012

\section{Introduction}

The detection of fetal abnormalities as well as its timing is of utmost importance to pregnant women. Ultrasonography has been proved to be the ideal and preferable non-invasive technique for the detection of fetal abnormalities. However, it necessitates repeatable and easily recognizable markers of fetal abnormalities. NT, which is an important sample to these markers, identifies fetuses with trisomy 21 or other major aneuploidies, skeletal dysplasia and cardiac defects in the first trimester. Another such important earlier recognizable sonographic marker which has been suggested for detection of spina bifida, is an intracranial translucency (IT) (1-3). It is actually the fourth cerebral ventricle, seen as anechoic 
behind the brain stem in the mid-sagittal plane of the fetal face, used for NT and nasal bone in the first trimester. Its absence or occlusion can be a sign of open spina bifida (1-3).

In this prospective study we aimed to determine normative values of IT in the population of Turkish singleton pregnant women, during the first trimester of pregnancy.

\section{Material and Methods}

Ethics committee approval was obtained for this prospective study. Between January 2011 and July 2011, all consecutive singleton pregnant women were screened for intracranial translucency as a part of first trimester fetal screening. Written informed consents were obtained for the study as a part of consent of first trimester screening. Ultrasonographic fetal screenings were performed by one of two sonographers using one of two ultrasound machines (Voluson 730 Expert (USA).

In the second trimester the pregnant women were screened for the "lemon" or "banana" sign for spina bifida as well as any other anatomical abnormalities. Pregnancies were followed up to birth. Pregnancies with any detected/suspicious anatomical or genetic fetal anomalies, biochemical abnormalities, increased nuchal translucency measurements, pregnancies of artificial reproduction techniques and anomaly detected at birth were excluded from the data analyses. Ultrasonographic evaluation and measurement of intracranial translucency had been performed in accordance with that previously stated in the literature (1-3). To measure IT, the exact mid-sagittal plane of the fetal face is obtained and the image is magnified to include the fetal head and upper thorax. The exact midsagittal plane of the fetal face is defined by the echogenic tip of the nose and rectangular shape of the palate anteriorly, the translucent thalamus in the center and the nuchal membrane posteriorly. In this plane, the fluid is identified within the third ventricle between the right and left thalami and the aqueduct of Sylvius between the cerebral peduncles, although the thalami and peduncles themselves are not visible. The two lines that define the IT are the posterior border of the brain stem anteriorly and the choroid plexus of the fourth ventricle posteriorly. At 11-13 weeks the brain stem appears hypoechogenic whereas the IT is anechoic. IT has a slightly curved appearance and the widest anteroposterior diameter is in the middle part of the fourth ventricle. It is recommended to select the translucency in the widest diameter placing the calipers on the anterior and posterior echogenic borders (1-3) (Example in Figure 1).

Mean \pm standard deviation, median and percentile values of the intracranial translucency were calculated. The linear regression analyses were done between the length of intracranial translucency and gestational week and CRL. Statistical analyses were done with SPSS ver. 14.0.

\section{Results}

During the study period, 206 pregnant women were screened for intracranial translucency and followed up. In five of them, intracranial translucency could not be measured in the first trimester but their follow-ups were normal and no anomaly was detected. Data analyses were done for the remaining 201 fetuses.

Median maternal age was 31 years (range 20-48). Median CRL was $62 \mathrm{~mm}$ (range 45-84). Median gestational week was 12.57 weeks (range $11^{+0}-13^{+6}$ ). Median IT value for the first trimester was $1.7 \mathrm{~mm}$ (range 1.00-2.40), reference percentile ranges are shown in Table 1. The measurement values of IT according to the CRL ranges are shown in Table 2. IT measurements increased with increasing CRL range $(p<0.001)$.

The equations of linear regression analyses of intracranial translucency measurements and gestational week and CRL are as follows; $(\mathrm{IT}(\mathrm{mm})=[0.237 \mathrm{xGestational} \mathrm{Week})]-1.27, \mathrm{R}^{2}=0.302$; $\mathrm{p}<0.001$ and IT $(\mathrm{mm})=[0.020 \mathrm{xCRL}(\mathrm{mm})]+0.44, \mathrm{R}^{2}=0.381$; $\mathrm{p}<0.001)$. The graphs of the linear regression analyses are

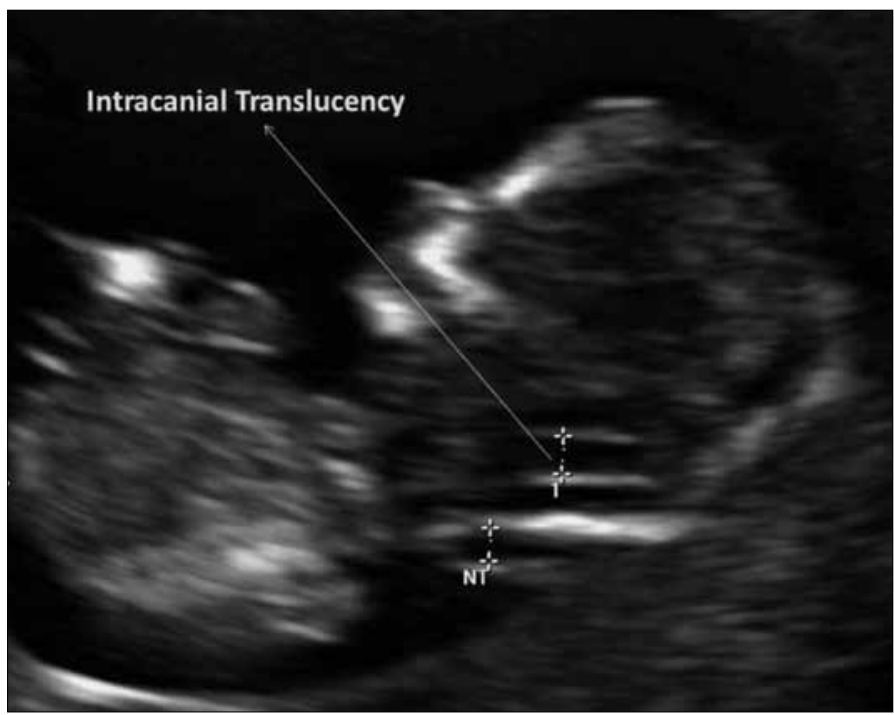

Figure 1. For the measurement of intracranial translucency, the exact mid-sagittal plane of the fetal face should be obtained and the image is magnified to include only the fetal head and upper thorax. The exact mid-sagittal plane of the fetal face has been defined by the echogenic tip of the nose and rectangular shape of the palate anteriorly, the translucent thalamus in the center and the nuchal membrane posteriorly

Table 1. Percentile values of IT

\begin{tabular}{|l|c|c|c|c|c|}
\hline \multirow{2}{*}{} & \multicolumn{5}{|c|}{ Percentiles } \\
\cline { 2 - 6 } & $\mathbf{5}$ & $\mathbf{2 5}$ & $\mathbf{5 0}$ & $\mathbf{7 5}$ & $\mathbf{9 5}$ \\
\hline IT (mm ) & 1.30 & 1.50 & 1.70 & 1.90 & 2.20 \\
\hline N.S.: Not significant, Mean Data \pm Standard Deviation, ${ }^{\text {a }}$. Median Value \\
\hline
\end{tabular}

Table 2. The values of IT according to CRL ranges

\begin{tabular}{|l|c|c|c|c|}
\hline CRL Ranges & Number & Mean & Std. Deviation & Median \\
\hline $45-54 \mathrm{~mm}$ & 38 & 1.46 & .22 & 1.40 \\
\hline $55-64 \mathrm{~mm}$ & 82 & 1.65 & .19 & 1.70 \\
\hline $65-74 \mathrm{~mm}$ & 68 & 1.84 & .24 & 1.85 \\
\hline $75-84 \mathrm{~mm}$ & 13 & 2.03 & .25 & 2.00 \\
\hline Total & 201 & 1.70 & .27 & 1.70 \\
\hline
\end{tabular}


seen in Figure 2 and Figure 3. IT measurements increased with increasing CRL and advancing gestational weeks.

During follow up, none of the 201 fetuses was found to have any anatomical abnormality or anomaly.

\section{Discussion}

With increasing knowledge and experience in fetal ultrasonography in the past decades, new repeatable and easily recognizable markers for fetal abnormalities have been suggested. Being one of above mentioned markers, absence of intracranial translucency has been suggested to be related to spina bifida, which can be scanned earlier in the first trimester compared to the "lemon" or "banana" sign in the second trimester screening (1-4). Although intracranial translucency

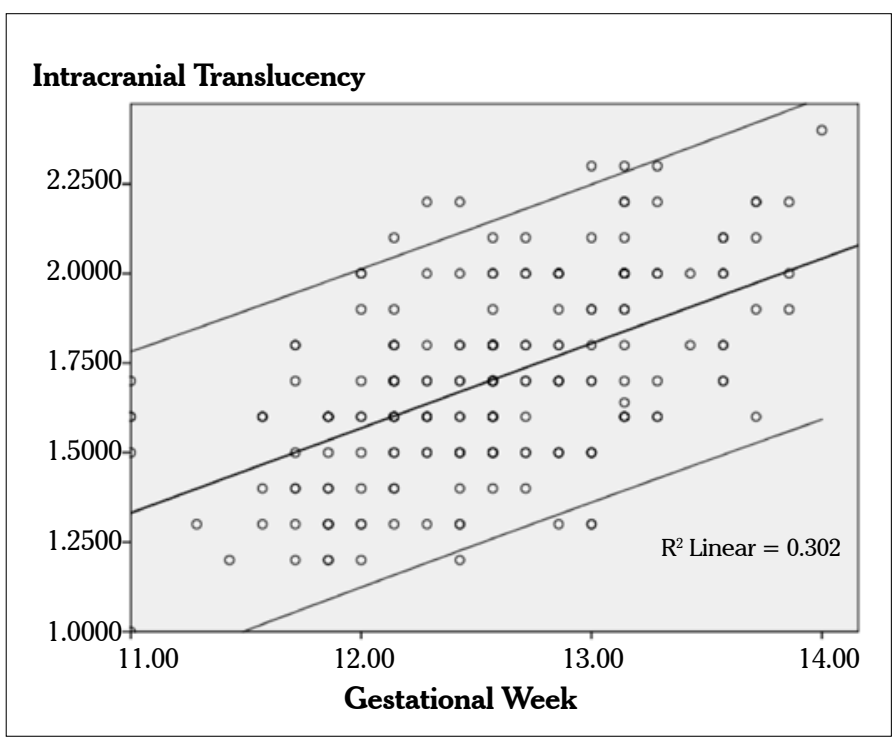

Figure 2. IT measurements according to gestational week (Lines indicating $95^{\text {th }}, 50^{\text {th }}, 5^{\text {th }}$ percentiles above to bottom respectively) measurement is mentioned as reproducible $(5,6)$, it has been shown that specific training increased visualization ratios of intracranial translucency (5). In this study, the retrospective series detection rate was $56-58 \%$ versus $91-92 \%$ in prospective series, indicating that experience as well as stored planes suitable for NT measurement may not always be suitable for IT visualization (5). In our study, experienced sonographers could not see intracranial translucency in five fetuses during the study period and they had no anomaly at birth. The prevalence of neural tube defects is approximately 1/1000 and our study population was lower, therefore absence of anomaly in our series might be due to this.

Although the absence of intracranial translucency has been suggested to be related to spina bifida; the intracranial translucency was reported to be normal in a case of 13 week fetus

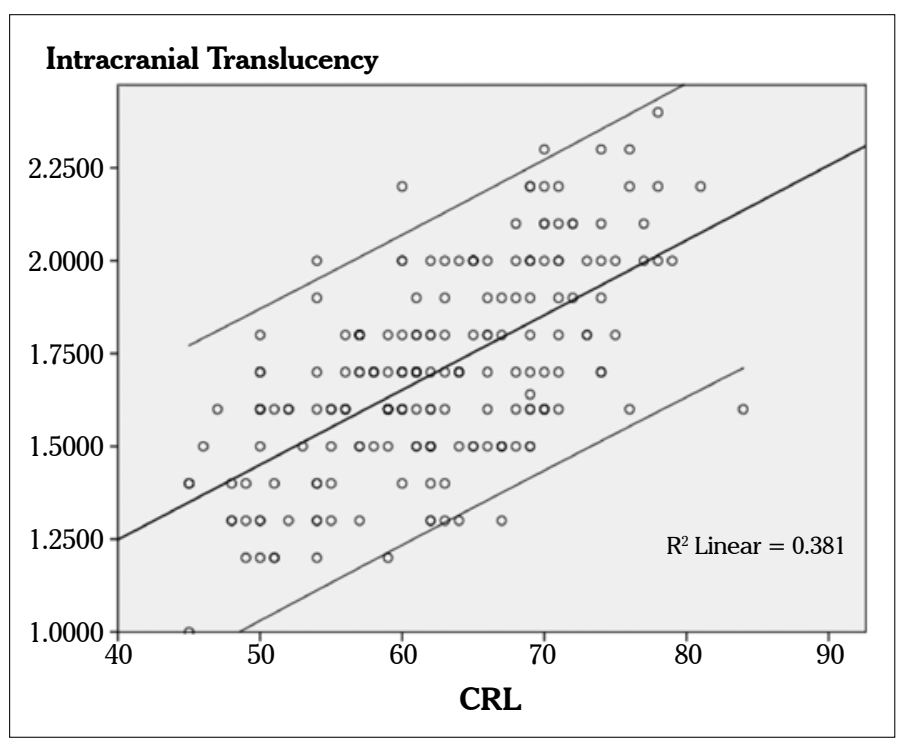

Figure 3. IT measurements according to CRL (Lines indicating $95^{\text {th }}, 50^{\text {th }}, 5^{\text {th }}$ percentiles above to bottom respectively)

Table 3. Different studies indicating intracranial translucency measurements in the first trimester of pregnancy

\begin{tabular}{|c|c|c|c|c|c|c|c|}
\hline $\begin{array}{l}\text { Type of Study / } \\
\text { Center }\end{array}$ & $\begin{array}{c}\text { Number of } \\
\text { fetuses }\end{array}$ & Median Age & Median CRL & $\begin{array}{c}\text { Median } \\
\text { Gestational } \\
\text { Week }\end{array}$ & $\begin{array}{c}\text { Formula of } \\
\text { intracranial } \\
\text { translucency }\end{array}$ & $\begin{array}{c}\text { IT at } 45 \mathrm{~mm} \\
\mathrm{CRL}^{*}\end{array}$ & $\begin{array}{c}\text { IT at } 84 \mathrm{~mm} \\
\text { CRL* }\end{array}$ \\
\hline $\begin{array}{l}\text { Retrospective } \\
\text { Multicenter } \\
\text { Europe (1) }\end{array}$ & 200 & NA & $\begin{array}{c}65 \mathrm{~mm} \\
\text { (Range 45-84) }\end{array}$ & $\begin{array}{c}12 \\
\text { (range } 11^{+0} \\
-13^{+6} \text { ) }\end{array}$ & NA & $1.5^{* *}$ & $2.5^{* *}$ \\
\hline $\begin{array}{l}\text { Prospective } \\
\text { China (6) }\end{array}$ & 111 & $\begin{array}{c}31 \text { years } \\
\text { (range } 20-44)\end{array}$ & $\begin{array}{c}64.6 \mathrm{~mm} \\
\text { (range } 48.5- \\
82.4)\end{array}$ & $\begin{array}{c}12^{+4} \\
\text { (range } 11^{+5} \\
\text { to } 13^{+4} \text { ) }\end{array}$ & $\begin{array}{c}(0.004 \times \mathrm{CRL}) \\
+1,63 \\
\left(\mathrm{R}^{2}=0.006\right)\end{array}$ & 1.8 & 2.0 \\
\hline $\begin{array}{l}\text { Prospective } \\
\text { Greece (9) }\end{array}$ & 611 & NA & NA & NA & $\begin{array}{c}(0.016 \times \mathrm{CRL}) \\
+0.803 \\
\left(\mathrm{R}^{2}=0.17\right)\end{array}$ & 1.5 & 2.1 \\
\hline $\begin{array}{l}\text { Prospective } \\
\text { Turkey } \\
\text { (Present } \\
\text { Study) }\end{array}$ & 201 & $\begin{array}{c}31 \text { years } \\
\text { (range } 20-48)\end{array}$ & $\begin{array}{c}62 \mathrm{~mm} \\
\text { (range } 45-84 \text { ) }\end{array}$ & $\begin{array}{l}12.57 \text { weeks } \\
\text { (range } 11^{+0} \\
13^{+6} \text { ) }\end{array}$ & $\begin{array}{c}(0.020 \times \mathrm{CRL}) \\
+0.44 \\
\left(\mathrm{R}^{2}=0.381\right)\end{array}$ & 1.3 & 2.1 \\
\hline
\end{tabular}


with spina bifida $(1,7)$. However, in a case series report, it has been noted that in some fetuses, fluid can be observed in the posterior brain and misdiagnosed as a 'normal IT' (3). In these cases with some fluid visualized, the typical posterior border of the IT was not identified and it was stressed that there was a thickened brainstem with an increased brainstem diameter to brainstem-occipital bone distance (BS/BSOB) (3). Also, in another retrospective study, a previously reported high degree of accuracy for detection of open spina bifida by assessment of IT at the 11-13-week scan was not confirmed (8). Rather, presence was accepted to be useful to exclude spina bifida (8). Also, fetal position was held responsible for non-visibility of intracranial translucency. The prone position was found to be related to a high ratio of non-visibility compared to the supine position (9).

The values related to various previous studies indicating intracranial translucency measurements, including the ones above mentioned, are shown in Table 3.

\section{Conclusion}

This study presents normative values of intracranial translucency in the first trimester screening of normal singleton pregnancies of the Turkish population. In accordance with previous reports, intracranial translucency increases linearly with advancing CRL.

\section{Conflict of interest}

No conflict of interest was declared by the authors.

\section{References}

1. Chaoui R, Benoit B, Mitkowska-Wozniak H, Heling KS, Nicolaides $\mathrm{KH}$. Assessment of intracranial translucency (IT) in the detection of spina bifida at the 11-13-week scan. Ultrasound Obstet Gynecol 2009; 34: 249-52. [CrossRef]

2. Chaoui R, Nicolaides KH. From nuchal translucency to intracranial translucency: towards the early detection of spina bifida. Ultrasound Obstet Gynecol 2010; 35: 133-8. [CrossRef]

3. Chaoui R, Benoit B, Heling KS, Kagan KO, Pietzsch V, Sarut Lopez A, et al. Prospective detection of open spina bifida at 11-13 weeks by assessing intracranial translucency and posterior brain. Ultrasound Obstet Gynecol 2011; 38: 722-6. [CrossRef]

4. Karl K, Kagan KO, Chaoui R. Intra- and interoperator reliability of manual and semi-automated measurements of the intracranial translucency. Ultrasound Obstet Gynecol 2012; 39: 164-8. [CrossRef]

5. Chen M, Chen H, Yang X, Wang HF, Yeung Leung T, Singh Sahota $\mathrm{D}$, et al. Normal range of intracranial translucency (IT) assessed by three-dimensional ultrasound at $11+0$ to $13+6$ weeks in a Chinese population. J Matern Fetal Neonatal Med 2011; 25: 489-92. [CrossRef]

6. Mangione $\mathrm{R}$, Lelong $\mathrm{N}$, Fontanges $\mathrm{M}$, Amat $\mathrm{S}$, Rosenblatt $\mathrm{J}$, Khoshnood B, et al. Visualization of intracranial translucency at the 11-13-week scan is improved after specific training. Ultrasound Obstet Gynecol. 2011; 38: 635-9. [CrossRef]

7. Arigita M, Martinez D, Nadal A, Borrell A. Spina bifida in a 13-week fetus with a normal intracranial translucency. Prenat Diagn 2011; 31: 1104-5. [CrossRef]

8. Fong KW, Toi A, Okun N, Al-Shami E, Menezes RJ. Retrospective review of diagnostic performance of intracranial translucency in detection of open spina bifida at the 11-13-week scan. Ultrasound Obstet Gynecol. 2011; 38: 630-4. [CrossRef]

9. Papastefanou I, Souka AP, Pilalis A, Panagopoulos P, Kassanos D. Fetal intracranial translucency and cisterna magna at 11 to 14weeks: reference ranges and correlation with chromosomal abnormalities. Prenat Diagn 2011; 31: 1189-92. 